\title{
A NEW GENUS AND SPECIES OF EUPODIDAE (ACARI: EUPODOIDEA) FROM MOSSES IN CRIMEA
}

\author{
Tyumen State University, Tyumen, Russia \\ E-mail: alex1973khaustov@gmail.com
}

Alexander A. Khaustov

ABSTRACT: The new genus Echinoeupodes gen. $\mathrm{n}$. is erected and a new species E. echinus sp. $\mathrm{n}$. is described from mosses in Crimea. Echinoeupodes turgidus (Shiba, 1978) comb. n. is transferred from Protereunetes.

KEY WORDS: Acarina, Prostigmata, Eupodoidea, systematics, morphology.

DOI: 10.21684/0132-8077-2017-25-1-29-44

\section{INTRODUCTION}

Mites of the cosmopolitan superfamily Eupodoidea Koch, 1842 are mycophagous, phytophagous and predatory. The classification of the superfamily lacks stability (Baker and Lindquist 2002). The superfamily Eupodoidea currently includes eight families: Eupodidae Koch, 1842; Penthaleidae Oudemans, 1931; Penthalodidae Thor, 1933; Rhagidiidae Oudemans, 1922; Strandtmanniidae Zacharda, 1979; Eriorhynchidae Qin and Halliday, 1997; Pentapalpidae Olivier and Theron, 2000; and Dendrochaetidae Olivier, 2009 (Khaustov 2014, $2015 \mathrm{a}, \mathrm{b})$. The family Eupodidae currently includes 12 genera (Khaustov 2014, 2015a). The eupodid mites inhabit soils, forest litter, mosses, lichens, seaweeds, mushrooms, etc. (Walter et al. 2009). Khaustov (2014) recently reviewed the taxonomy of the superfamily Eupodoidea and provided a key to genera of the family Eupodidae. He also redefined the genus Niveupodes Barilo, 1991 and redescribed its type species N. niveus Barilo, 1991 (Khaustov 2016). The family Eupodidae is insufficiently studied in Russia, and only recently Khaustov (2014, 2015a) described two new genera Pseudoeupodes Khaustov, 2014 with type species P. porosus Khaustov, 2014 and Pseudopenthaleus Khaustov, 2015 with type species $P$. tauricus Khaustov, 2015 from the Crimean peninsula. This paper presents a description of another new genus and species of eupodid mite, Echinoeupodes echinus gen. n., sp.n., collected from mosses in Crimea.

\section{MATERIAL AND METHODS}

Mites were collected from mosses using Berlese funnels and mounted in Hoyer's medium. Notations for the prodorsal and leg setae follow those of Lindquist and Zacharda (1987) and Baker (1995), and the remaining nomenclature is that applied to eupodoids by Baker (1990). All measure- ments are given in micrometres $(\mu \mathrm{m})$. In the descriptions of leg setation the number of solenidia is given in parentheses. Photographs were taken with a digital cameras AxioCam ICc5 (Zeiss, Germany) and Hitachi KP-HD20A (Japan) via a compound microscope AxioImager A2 (Zeiss, Germany) with phase-contrast and DIC objectives. The type material is deposited in the mite collection of the Tyumen State University Museum of Zoology, Tyumen, Russia.

\section{SYSTEMATICS}

\section{Family Eupodidae Koch, 1842}

Genus Echinoeupodes gen. n.

Type species: Echinoeupodes echinus sp. n.

Diagnosis. Female. Idiosomal dorsum. Idiosoma oval. Cuticle very soft, covered by numerous needle-like projections (Fig. 1B). Sejugal furrow absent. Prodorsum with three pairs of tactile setae $\left(v_{1}, v_{2}, s c_{2}\right)$, and a pair of filiform trichobothria $\left(s c_{1}\right)$. Naso (epivertex) not separated from rest of prodorsum or weakly separated. Hysterosoma with eight pairs of dorsal setae $\left(c_{1}, c_{2}, d_{1}, e_{1}, f_{1}, f_{2}, h_{1}, h_{2}\right)$ and three pairs of oval lyrifissures ( $i a, i m, i p)$. All dorsal hysterosomal setae short, pinnate (Fig. 1B).

Idiosomal venter. Cuticle between coxae striate, with long cuticular projections. Coxisternal setal formula 3-1-4-3; four pairs of eugenital setae; six pairs of genital setae; four pairs of aggenital setae; two or three pairs of pseudanal setae $\left(p s_{1}-\right.$ $p s_{3}$ ); one pair of lyrifissures $(i h)$, same form as dorsals, two pairs of genital acetabulae large, oval. Anal opening small, situated ventrally.

Gnathosoma. Palp setal formula 0-2-3-8(Ф), tarsus oval. Palpal solenidion very long. Chelicerae: typical for eupodid mites, movable digit slender and acuminate distally, fixed digit slightly 


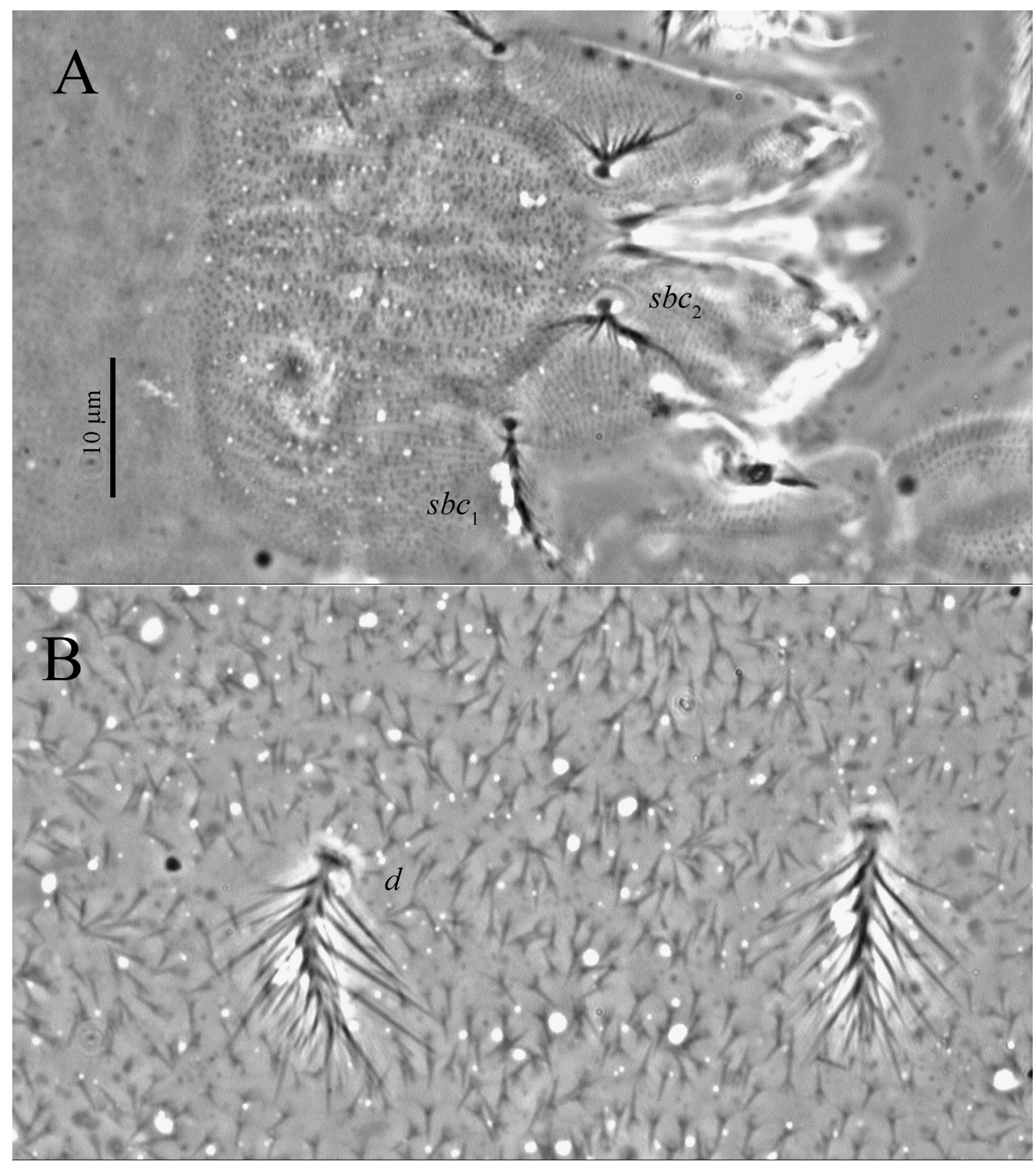

Fig. 1. Echinoeupodes echinus sp. n., female: A — subcapitulum, B — dorsal integument and setae $d$.

shorter than movable digit and with spine-like projection distally; seta cha present. Subcapitulum with two pairs of subcapitular setae $\left(s b c_{1-2}\right) ; s b c_{1}$ sparsely pilose, $s b c_{2}$ very wide, fan-like, with very long barbs; and two pairs of smooth adoral setae $\left(o r_{1-2}\right)$. Pharynx narrow, continuing in an unusually very long oesophagus.

Legs. All legs shorter than body. All tarsi with a pair of simple claws and tongue-like empodium covered by numerous long projections. Soft cuticle separating coxisternal plates and trochanters of all legs without pore-like structure. Rhagidial organ I
(Figs. 4A, 8A, B) with two parallel long solenidia; rhagidial organ II (Fig. 5A) with three parallel long rhagidial solenidia. Rhagidial organs I and II bordered by longer cuticular projections. Tarsus I with large famulus (stellate setae) situated in shallow depression; tarsus II with short spine-like famulus covered by posterior part of rhagidial solenidion $\omega_{1}$. Tibia I with one distal long rhagidial solenidion, small famulus $k$ covered by anterior part of solenidion $\varphi_{1}$ and basal erect solenidion; tibia II with distal semierect solenidion and proximal erect solenidion; tibiae III and IV with proximal erect solenidion. Femur 


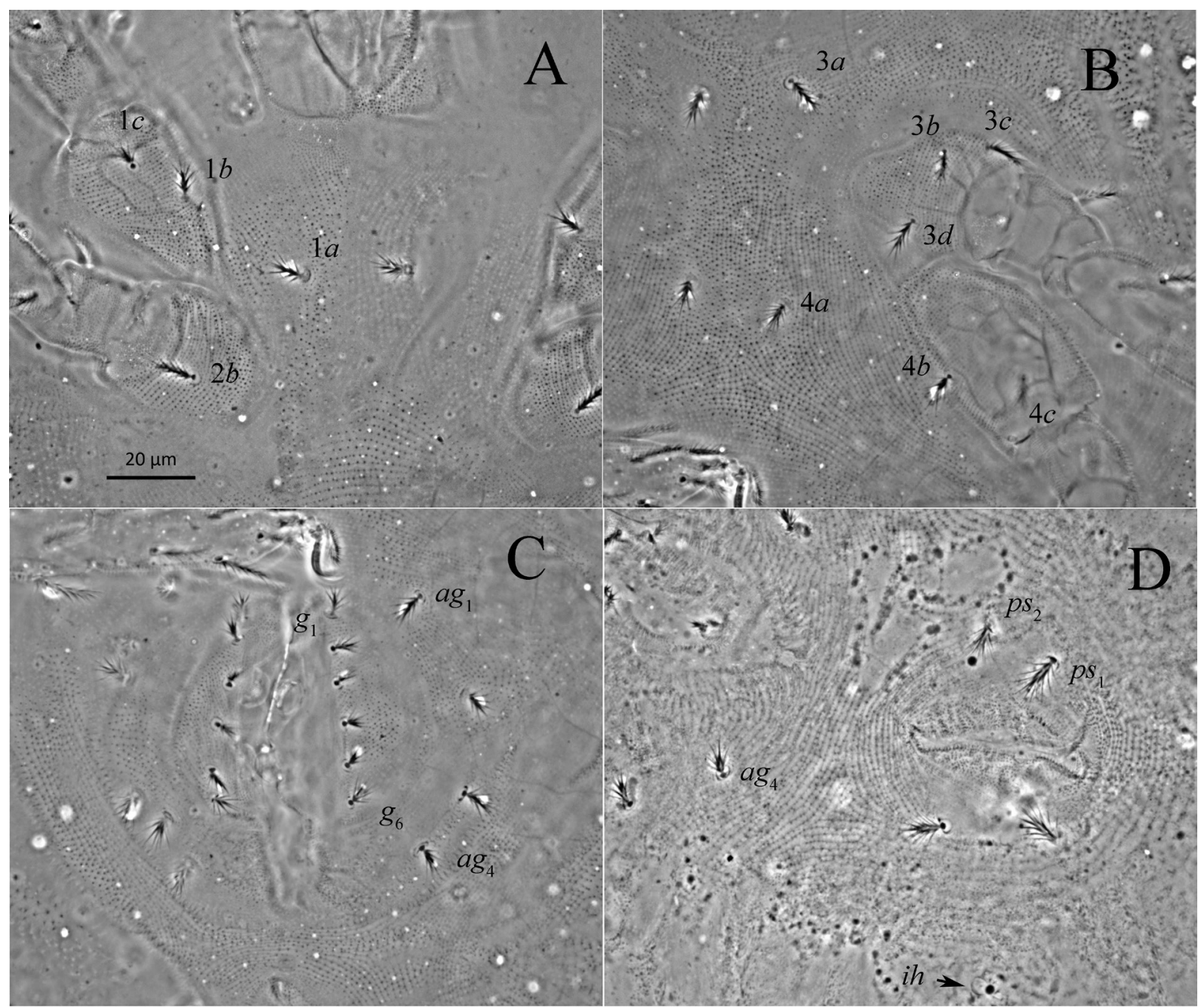

Fig. 2. Phase-contrast micrographs of Echinoeupodes echinus sp. n., female: A—sternocoxal fields I-II, B-sternocoxal fields III-IV, C—genital area, D_-anal area.

IV not enlarged. Only femur IV divided into basi- and telofemur. Trochanteral setal formula 1-1-1-1.

Deutonymph. In general, similar to female. Coxisternal setal formula 3-1-4-2. Two pairs of genital and aggenital setae. Eugenital setae absent. Rhagidial organ II with two rhagidial solenidia. Trochanter IV without setae.

Male and other immatures. Unknown.

Species included. The genus Echinoeupodes includes two species: E. echinus sp. n. from Crimea and E. turgidus (Shiba, 1978) comb. n. (from Protereunetes) from Japan (Shiba 1978).

Differential diagnosis. The new genus differs from all known genera of the family Eupodidae by parallel rhagidial setae in rhagidial organs I and II (usually longitudinally aligned in other genera) and by the presence of unpaired ventral seta $v s$ on tarsi I-IV located between and slightly posteriad to setae $p v$ (absent in all known eupodoid mites).

Etymology. The name of the new genus is a

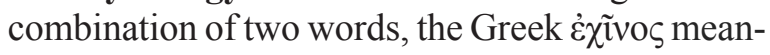

ing hedgehog, and Eupodes, the type genus of the family Eupodidae.

\section{Echinoeupodes echinus sp. $\mathrm{n}$.}

(Figs. 1-14)

Description. Female (Figs. 1-8). Alive mites of a milky color. Body oval. Length of idiosoma 345 , width at level of setae $c_{2} 230$.

Idiosomal dorsum. Lyrifissures ia situated posterolaterally to bases of setae $c_{1}$; im situated anterolaterally to bases of setae $e_{1}$; ip situated anteriorly to bases of setae $f_{2}$. Lengths of dorsal setae: $v_{1} 11, v_{2} 16, s c_{1} 51, s c_{2} 18, c_{1} 25, c_{2} 25, d_{1} 27, e_{1} 27$, $f_{1} 28, f_{2} 25, h_{1} 27, h_{2} 24$.

Idiosomal venter (Fig. 2). All ventral setae short and densely pilose. Genital setae subequal and arranged in one longitudinal row. Aggenital setae subequal in length. Eugenital setae situated on protuberances. Lyrifissure ih located laterally to setae $p s_{2}$. Coxisternal plates I-II and 


\section{A. A. Khaustov}
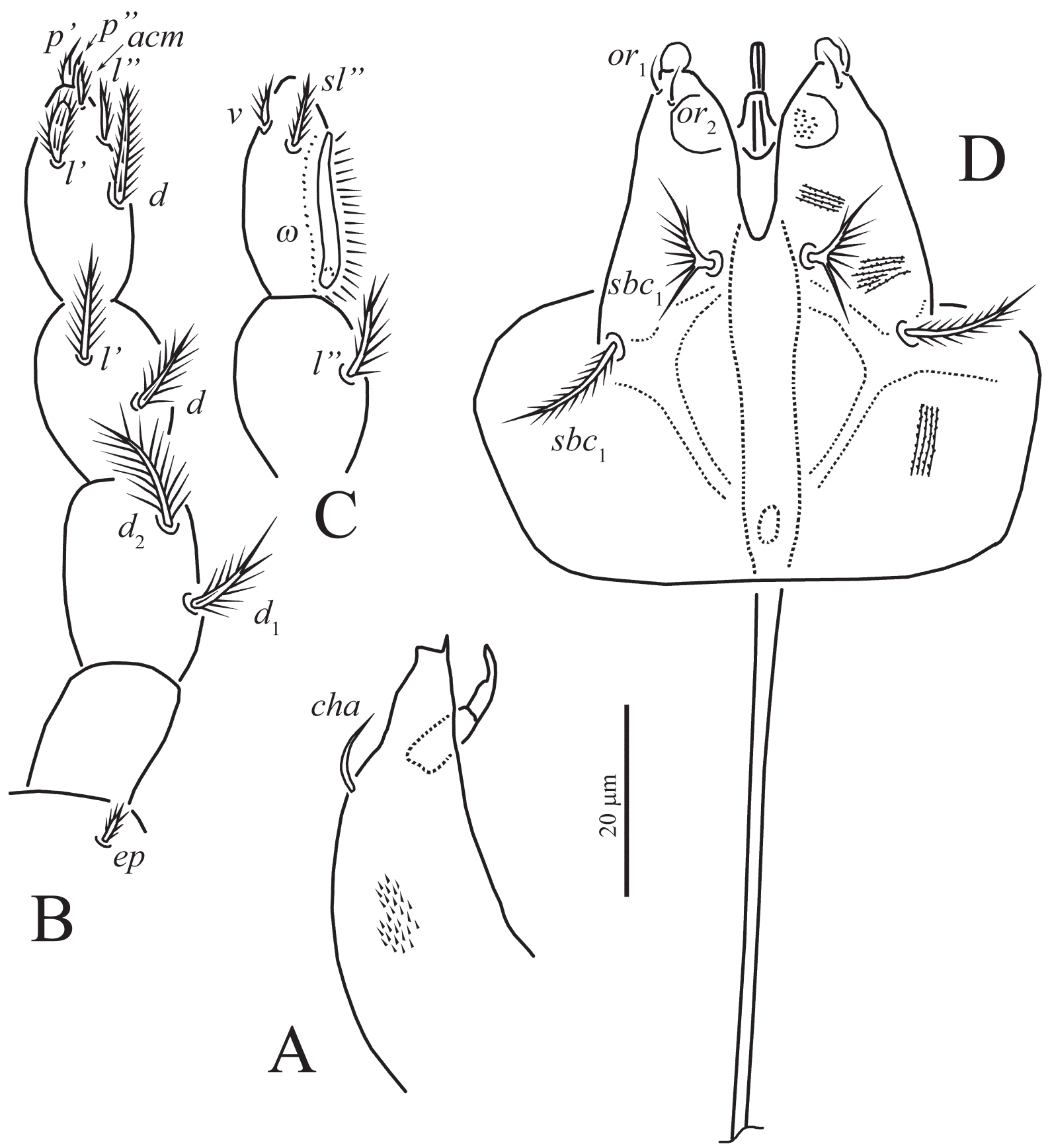

Fig. 3. Echinoeupodes echinus sp. n., female: A—chelicera in lateral view, B-palp in dorsal view, C-palpal tibia and tarsus in ventral view, D-subcapitulum.

III-IV with weak subcuticular reticulation (Figs. 2A, B).

Gnathosoma (Fig. 3). Integument papillate. Subcapitulum (Figure 3D) roughly triangular, with two pairs of minute smooth adoral setae $\left(o r_{1}, o r_{2}\right)$, located subapically; subcapitular setae $s b c_{1}$ sparsely pilose, $s b c_{2}$ short and wide, fan-like, with long barbs, $s b c_{1}$ located laterally at level of proximal margin of palp trochanters, $s b c_{2}$ inserted ventrally two-thirds to three-quarters of distance between $s b c_{1}$ and tip of subcapitulum, labrum distinctly rounded. Chelicera (Figure 3A) with spiculate cuticle, seta cha smooth, pointed. Palps (Figs. 3B, C) with supracoxal seta $e p$ minute, brush-like, femorogenual and tibial setae pinnate, tarsal setae $l$ 'thickened and flattened, other tarsal setae pilose, $\omega$ almost as long as palptarsus.

Legs (Figs. 4-8). Lengths of legs: I 245, II 170, III 170, IV 220. All tactile leg setae pinnate. Setal homologies as on figures 4-7. Leg I (Figs. 4, 8): supracoxal setae $e l$ of the same shape and length as palpal supracoxal setae $e p$. Setal formula: Tr-1,

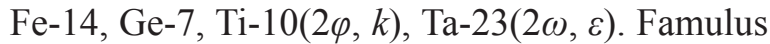
$\varepsilon$ (stellate seta) large, located in a shallow depres- 

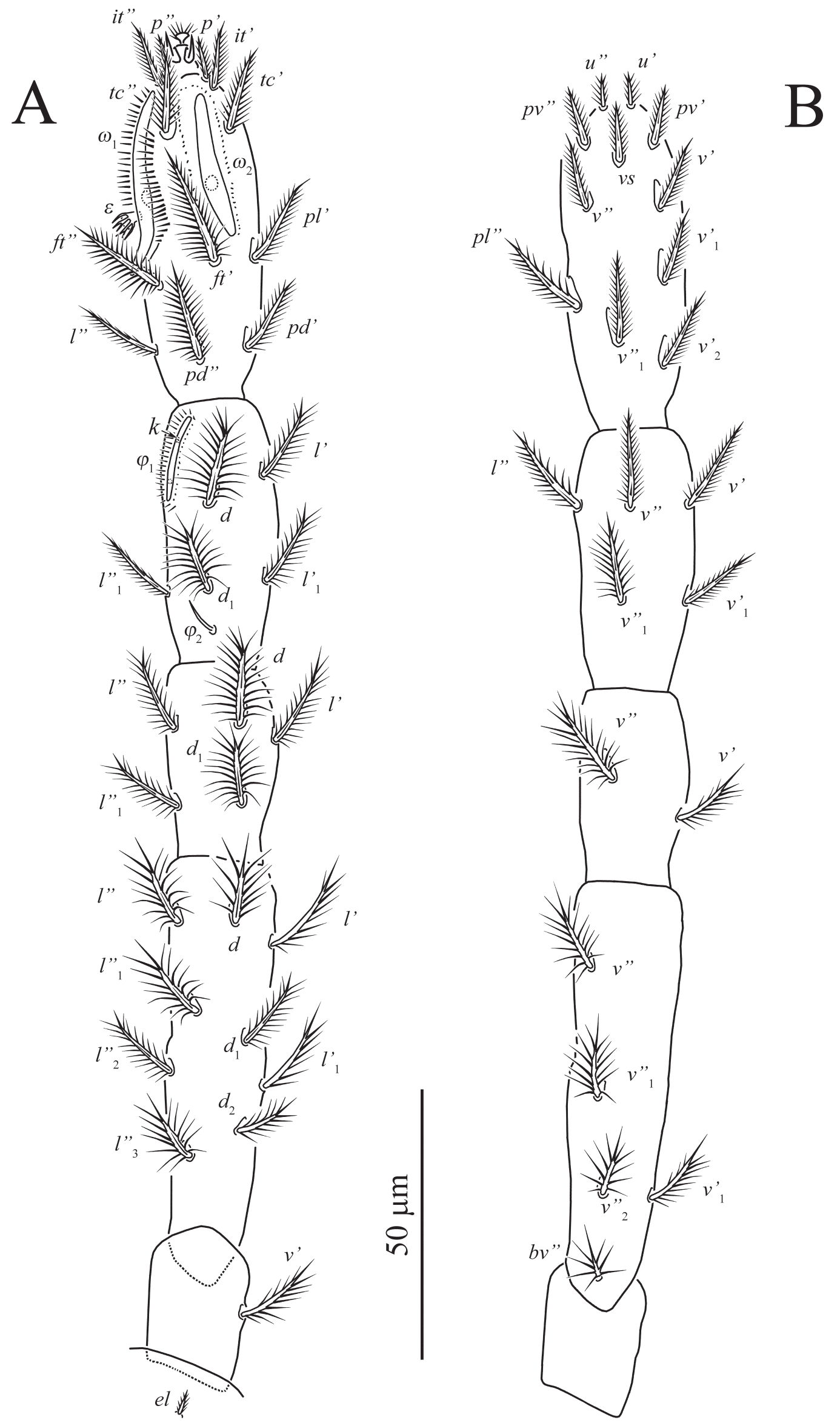

Fig. 4. Echinoeupodes echinus sp. n., female: A—leg I in dorsal view, B-leg I in ventral view. 


\section{A. A. Khaustov}
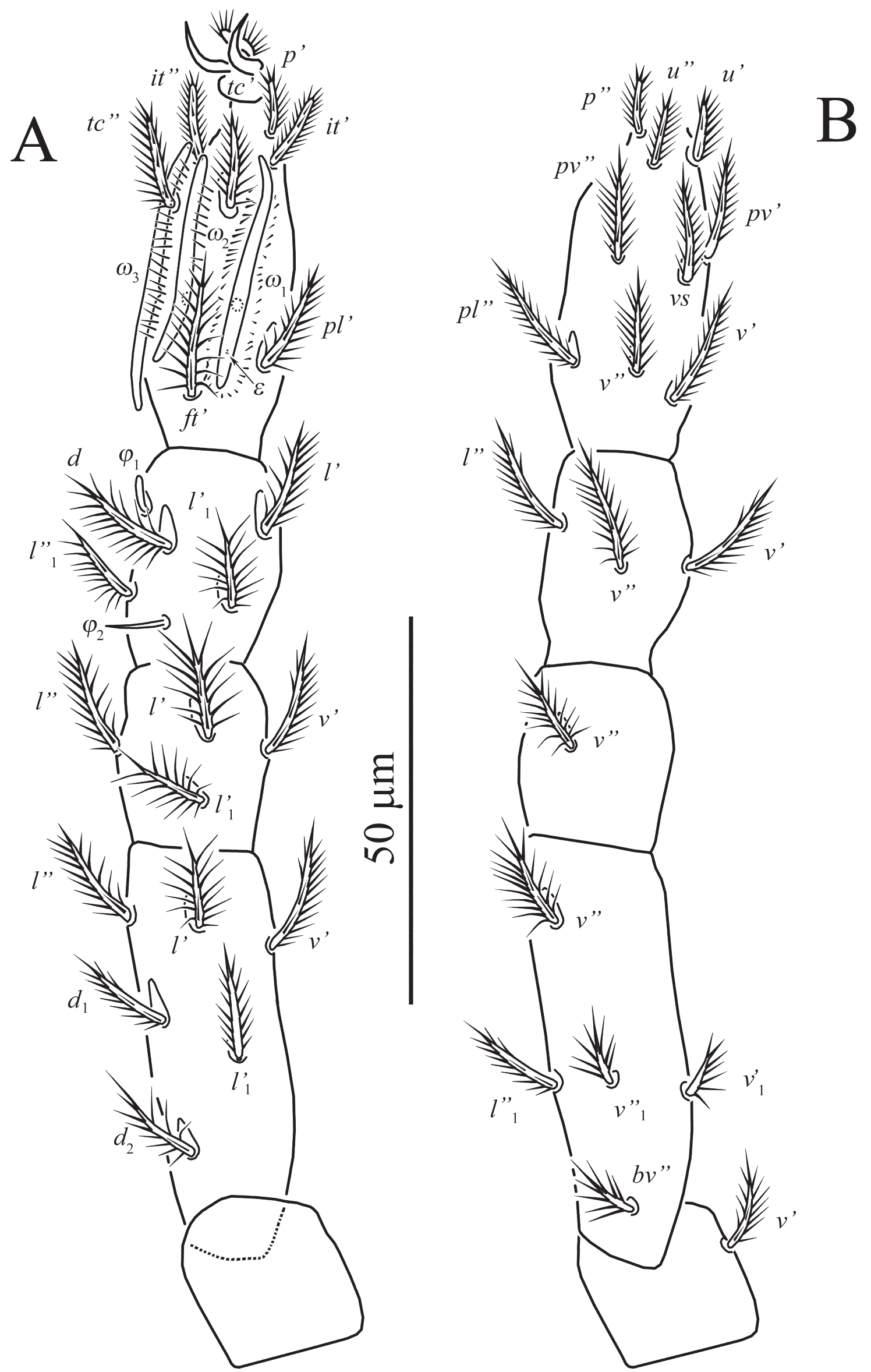

Fig. 5. Echinoeupodes echinus sp. n., female: A-leg II in dorsal view, B-leg II in ventral view. 


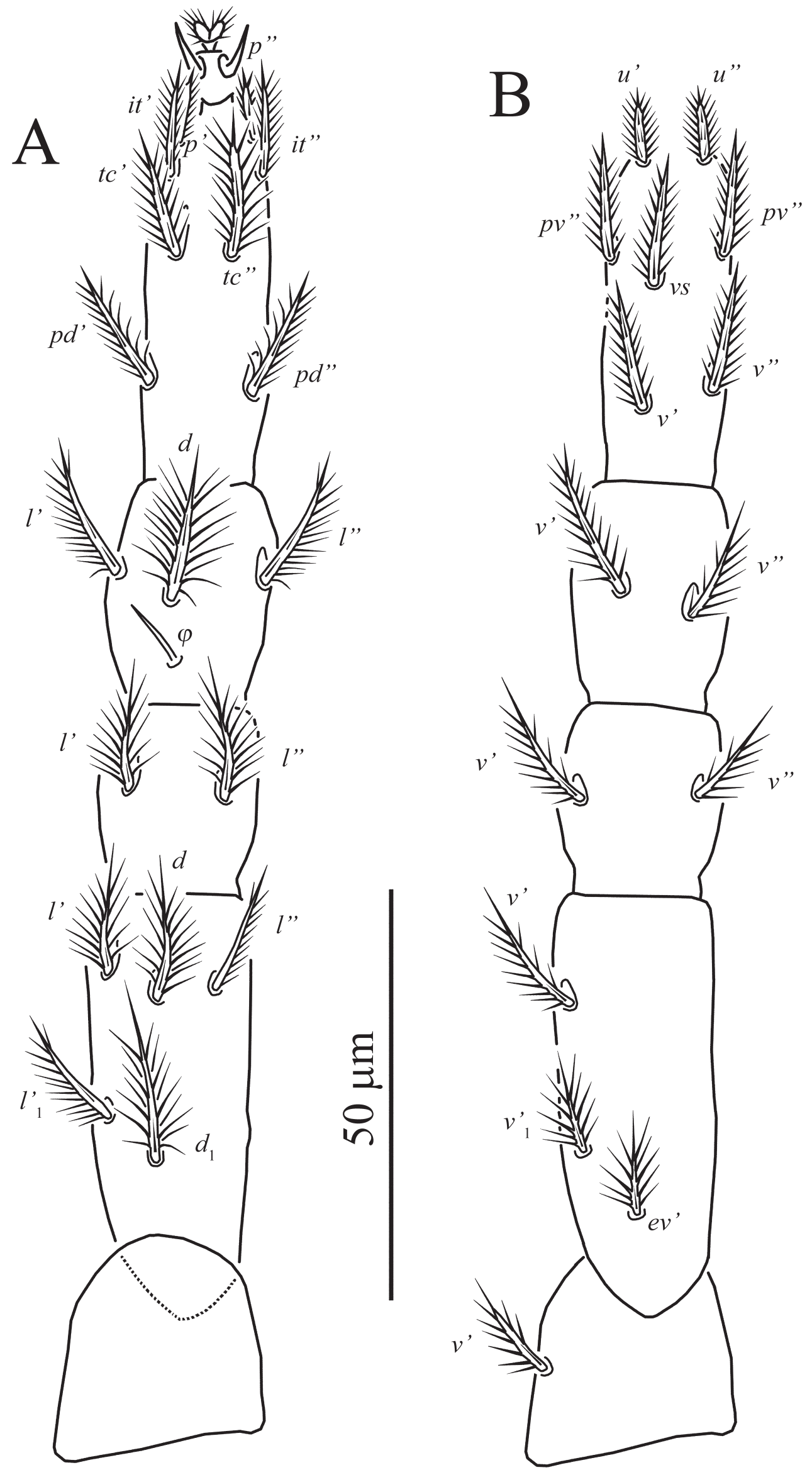

Fig. 6. Echinoeupodes echinus sp. n., female: A-leg III in dorsal view, B-leg III in ventral view. 


\section{A. A. Khaustov}
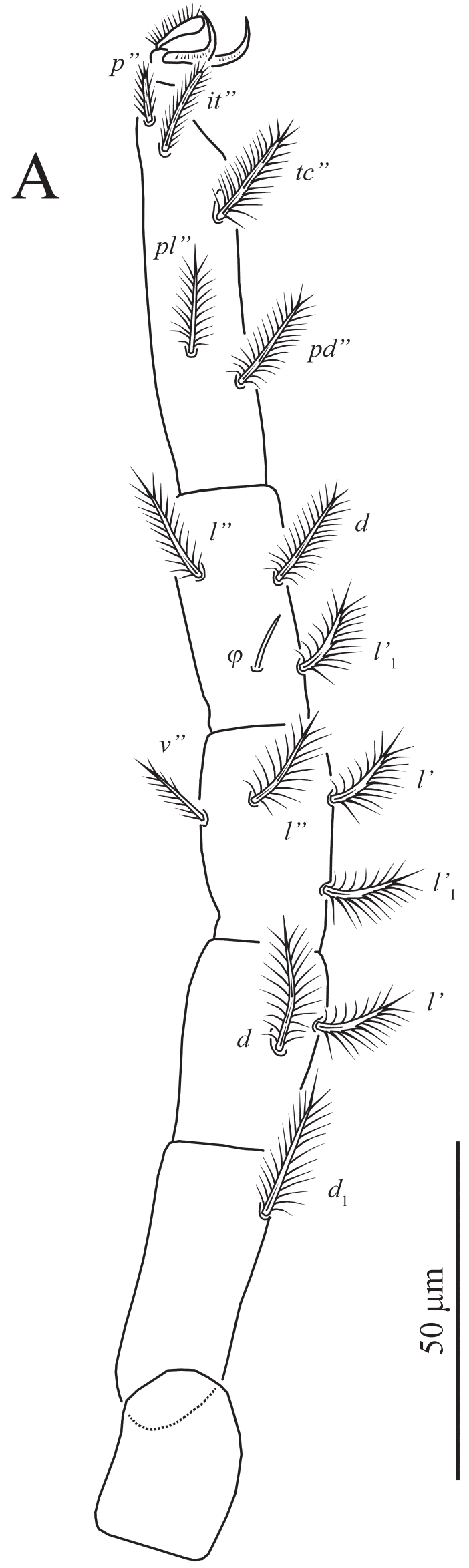
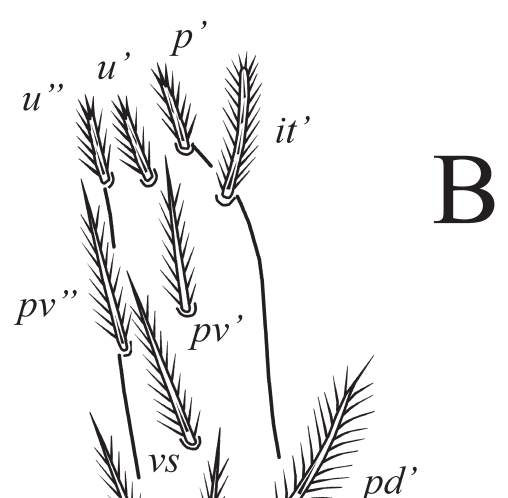

$p d^{\prime}$
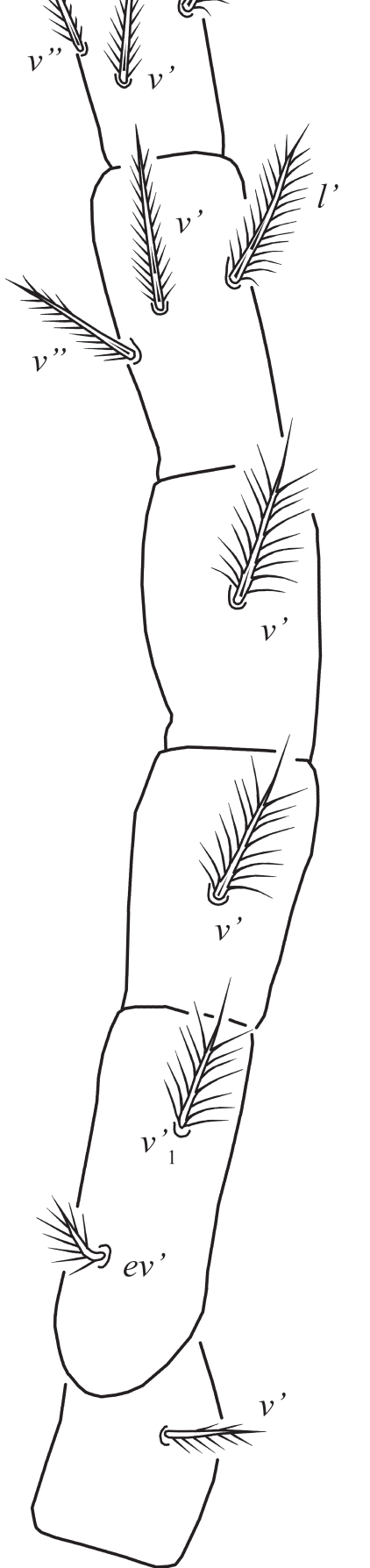

Fig. 7. Echinoeupodes echinus sp. n., female: A—leg IV in dorsal view, B-leg IV in ventral view. 


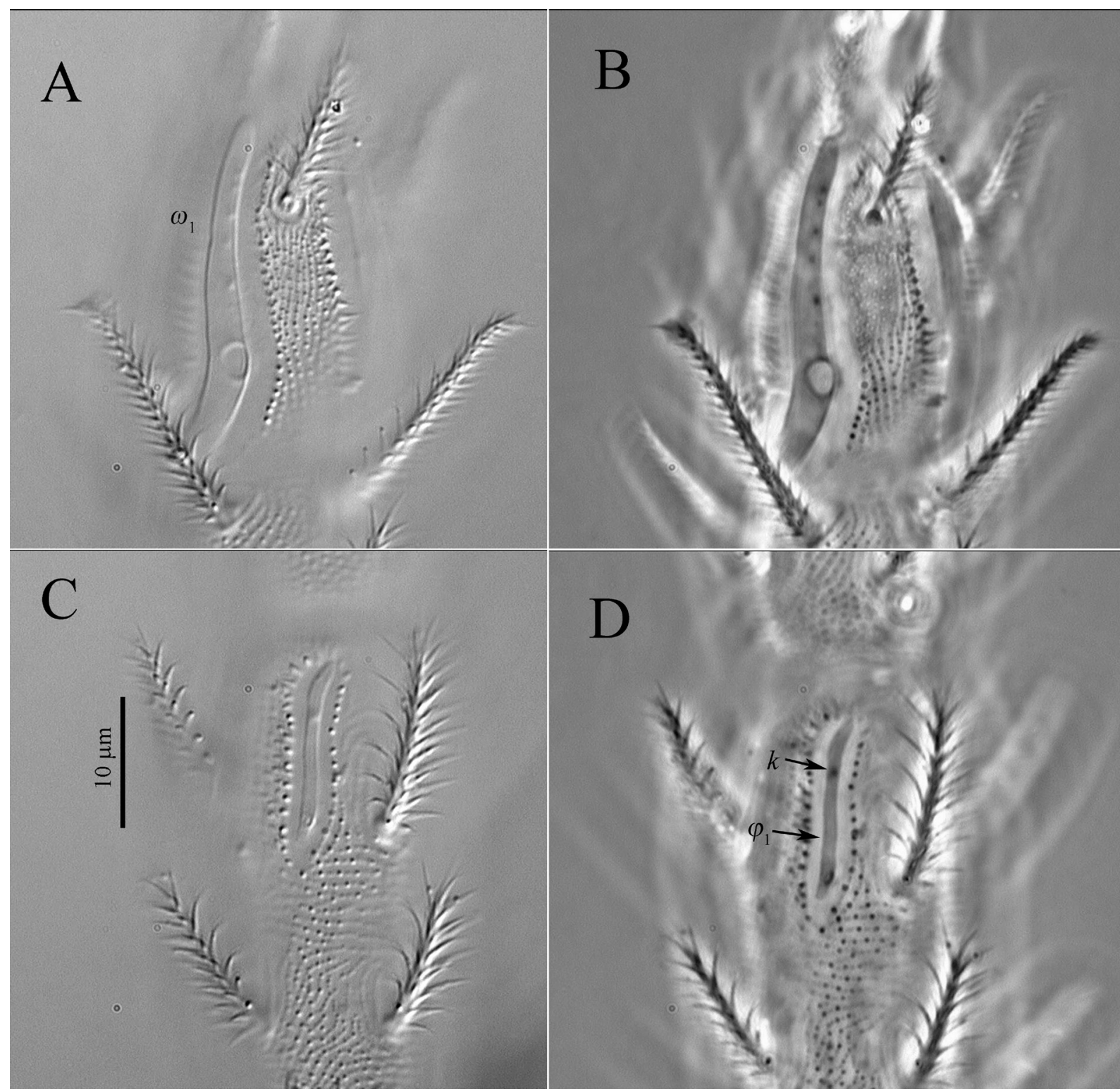

Fig. 8. DIC (A, C) and phase-contrast (B, D) micrographs of Echinoeupodes echinus sp. n., female: A, B-tarsus I in dorsal view, B, D-tibia I in dorsal view.

sion laterally to basal part of rhagidial solenidion $\omega_{1}$ and oriented posteriorly. Rhagidial solenidion $\varphi_{1}$ longitudinally oriented, dorsodistal and situated in shallow depression together with minute famulus $k$; solenidion $\varphi_{2}$ short, proximodorsal. Leg II

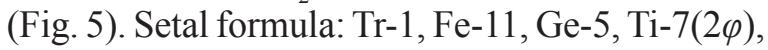
Ta-16 $(3 \omega, \varepsilon)$. Famulus $\varepsilon$ very small, spine-like, located posteriorly to base of rhagidial solenidion $\omega_{1}$ and covered by its posterior part. Rhagidial solenidion $\varphi_{1}$ dorsodistal, semierect, distinctly blunt-ended and situated in shallow depression; solenidion $\varphi_{2}$ proximodorsal. Leg III (Fig. 6): Setal formula: Tr-1, Fe-8, Ge-4, Ti-5( $\varphi$ ), Ta-15; solenidion $\varphi$ proximodorsal. Leg IV (Fig. 7): Setal formula: Tr-1, Fe-3+3, Ge-5, Ti-6( $\varphi$ ), Ta-15; solenidion $\varphi$ proximodorsal.
Deutonymph (Figs. 8-14). Length of idiosoma 315, width at level of setae $c_{2} 190$.

Idiosomal dorsum (Fig. 9) as in female. Lengths of dorsal setae: $v_{1} 7, v_{2} 14, s c_{1} 50, s c_{2}$ $15, c_{1} 21, c_{2} 20, d_{1} 20, e_{1} 21, f_{1} 19, f_{2} 18, h_{1} 20$, $h_{2} 18$.

Idiosomal venter (Fig. 10) as in female, except presence of two pairs of genital and aggenital setae, absence of eugenital setae and presence of only two pairs of setae on coxisternal fields IV (Fig. 10C).

Gnathosoma as in female.

Legs (Figs. 11-14). Lengths of legs: I 185, II 135, III 140, IV 165. Setal homologies as on figures 11-14. Leg I (Fig. 11): Setal formula: Tr-1, Fe-9,

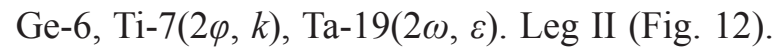

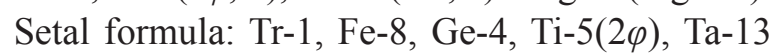




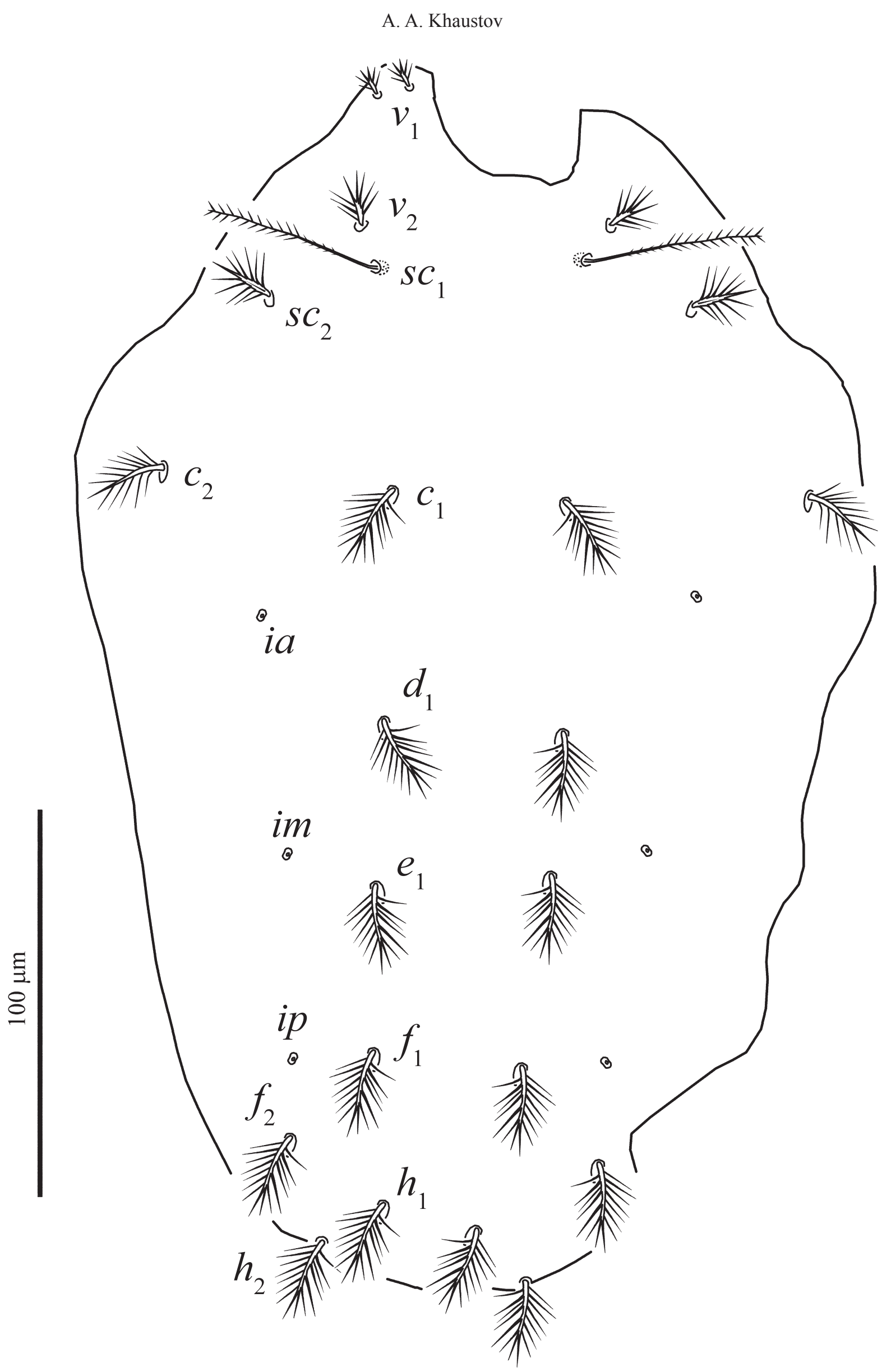

Fig. 9. Echinoeupodes echinus sp. n., deutonymph: idiosomal dorsum. 


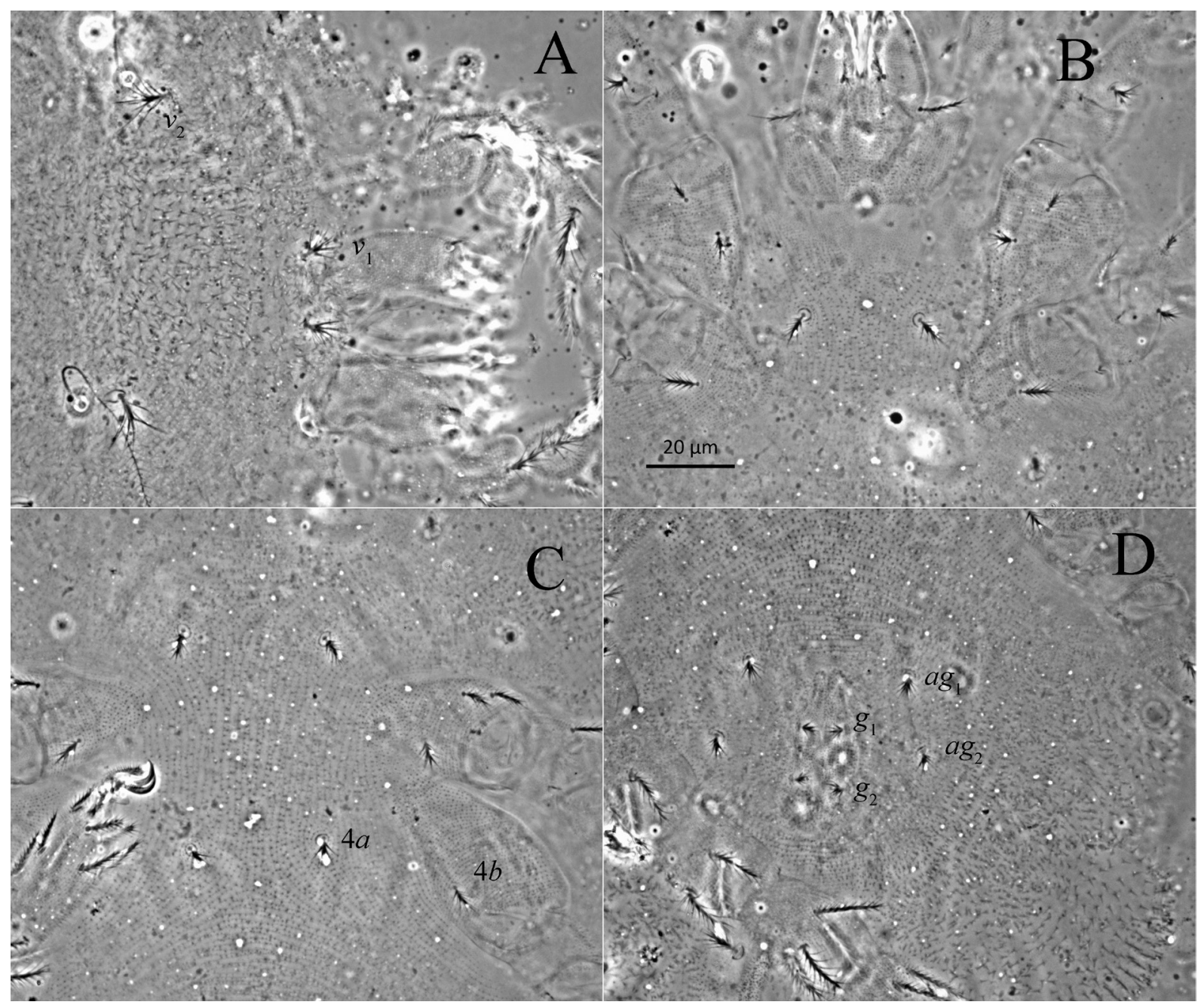

Fig. 10. Phase-contrast micrographs of Echinoeupodes echinus sp. n., deutonymph: A—prodorsum, B—sternocoxal fields I-II, C—-sternocoxal fields III-IV, D—genital area.

$(2 \omega, \varepsilon)$. Leg III (Fig. 13): Setal formula: Tr-1, Fe-7, Ge-4, Ti-4( $\varphi$ ), Ta-11. Leg IV (Fig. 14): Setal formula: Tr-0, Fe-1+3, Ge-3, Ti-4( $\varphi)$, Ta-11.

Type material. Holotype female, slide \# AK020114, Crimea, vicinity of Yalta, moss on soil in oak forest, 2 January 2014, coll. A.A. Khaustov. Paratypes: 1 female and 2 deutonymphs same data as holotype, 1 deutonymph, same place, 8 February 2014, 1 deutonymph same place, 3 January 2000; 1 deutonymph same place, 26 January 1994; 1 deutonymph same place, 12 March 1994.

Differential diagnosis. The new species differs from E. turgidus (Shiba, 1978) comb. n. by the presence of two pairs of pseudanal setae (three pairs in E. turgidus) and by naso not separated from prodorsum (weakly separated in E. turgidus).

Etymology. The name of the new species de-

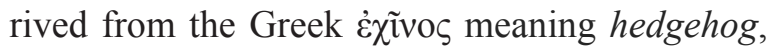
and refers to the presence of numerous long needlelike cuticular projections.

\section{DISCUSSION}

The new genus is characterized by the combination of unique characters for the family Eupodidae. The parallel orientation of the rhagidial solenidia in the rhagidial organs I and II is not recorded in other genera of Eupodidae. Only in some Cocceupodes Thor, 1934 rhagidial solenidia in rhagidial organs more or less parallel (Jesionowska 2007), but the bases of solenidia situated on different longitudinal levels. The typical parallel rhagidial organs are known in the family Rhagidiidae (Zacharda 1980). Rhagidial organs of Echinoeupodes gen. n. are most similar to those of the rhagidiid genus Shibaia Zacharda, 1980. In both genera rhagidial solenidia are unusually long. Another unique character is the presence of unpaired ventral seta on tarsi I-IV located between the pair of setae $p v$. In this article, I designated it as vs (Grandjean 1944). This unpaired setae is unknown in any taxa of the superfamily Eupodoidea (Baker 1990). The pharynx of Echinoe- 


\section{A. A. Khaustov}
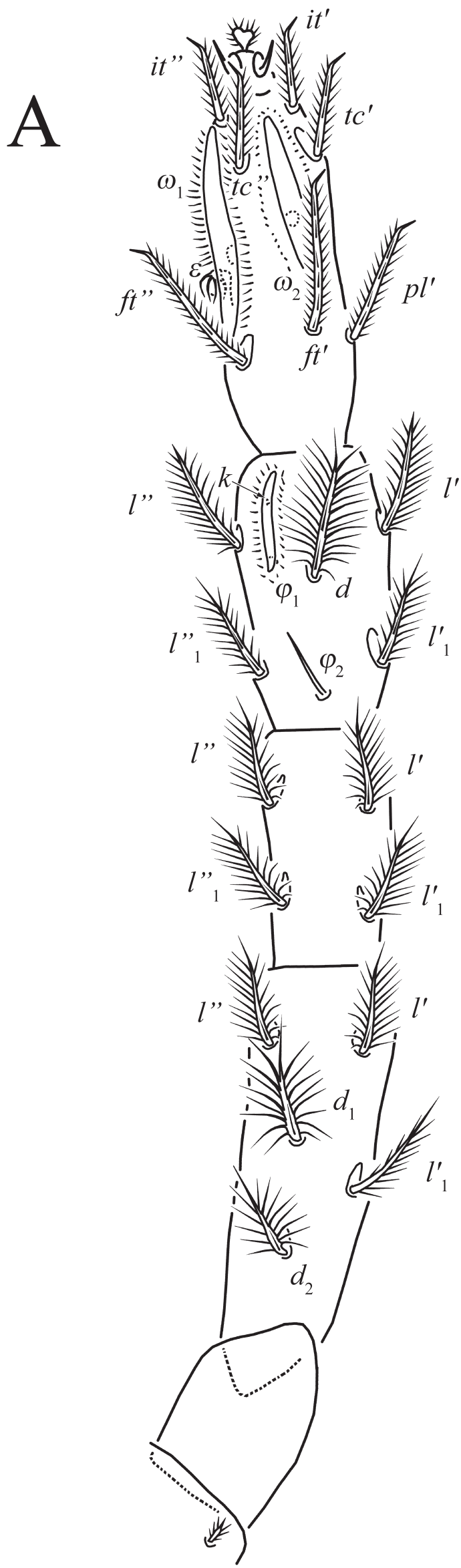

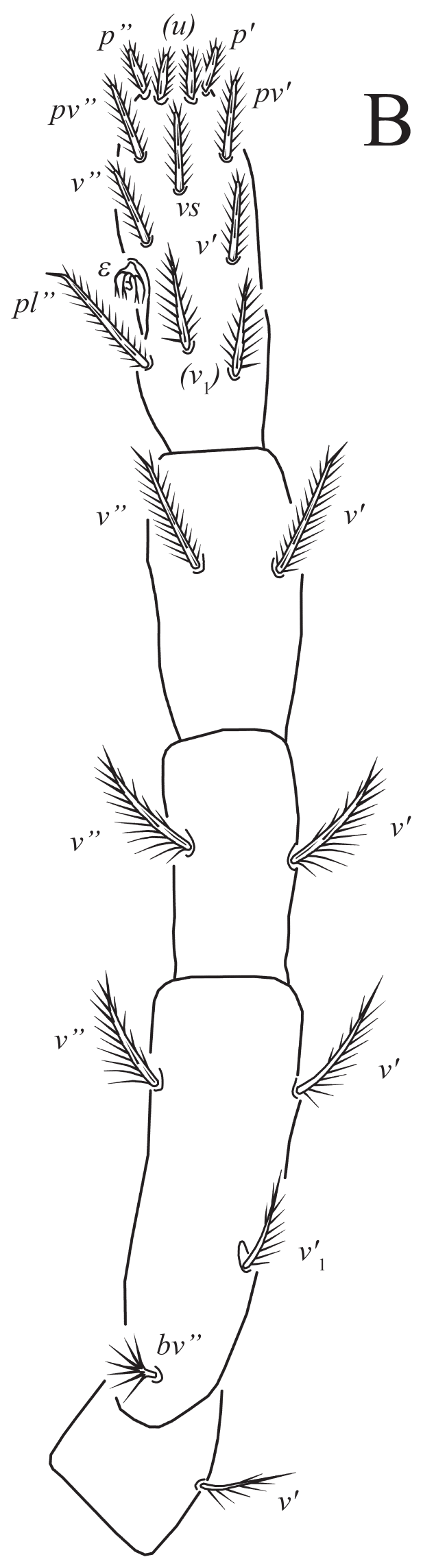

Fig. 11. Echinoeupodes echinus sp. n., deutonymph: A-leg I in dorsal view, B-leg I in ventral view. 

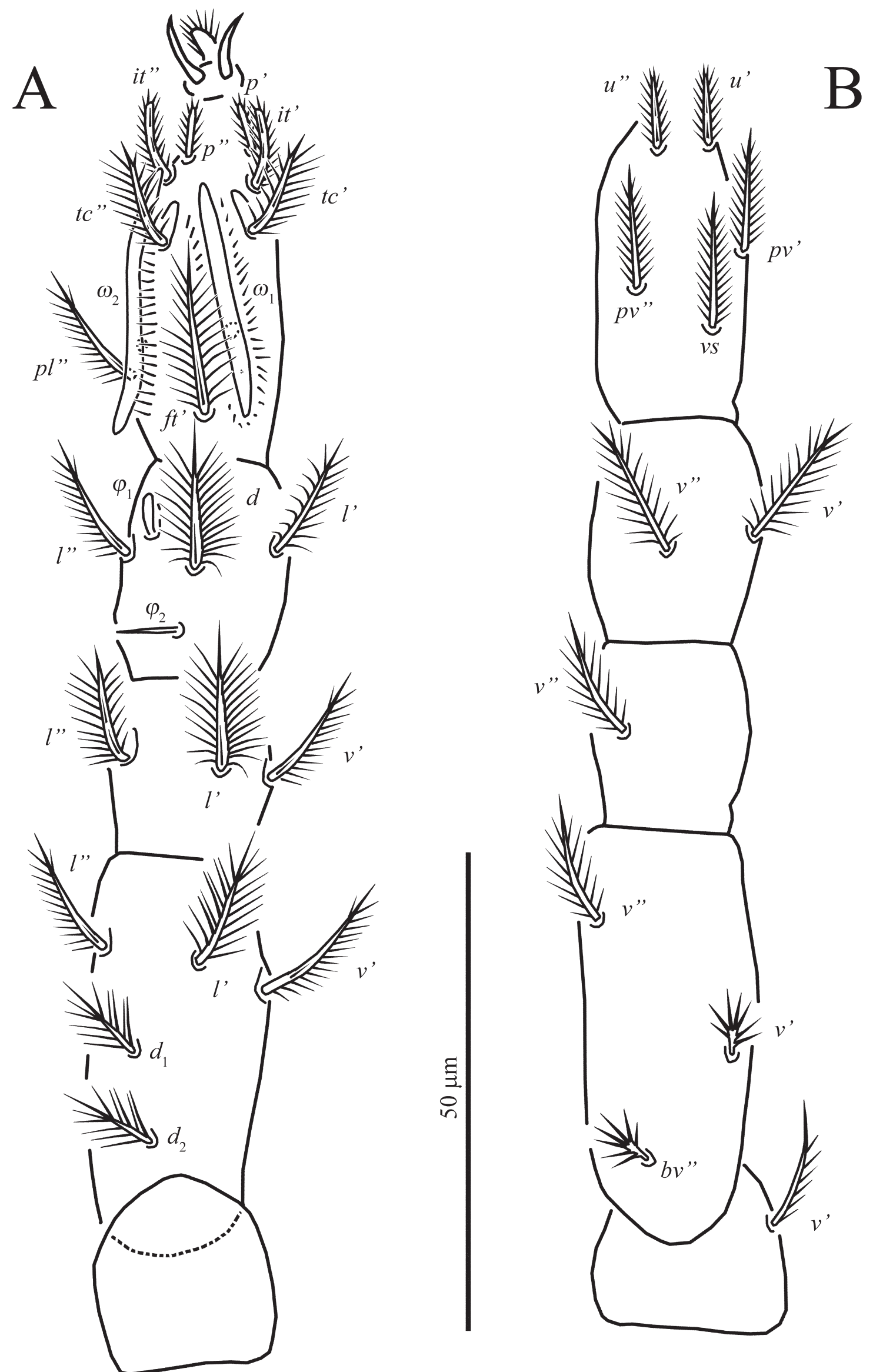

Fig. 12. Echinoeupodes echinus sp. n., deutonymph: A-leg II in dorsal view, B-leg II in ventral view. 

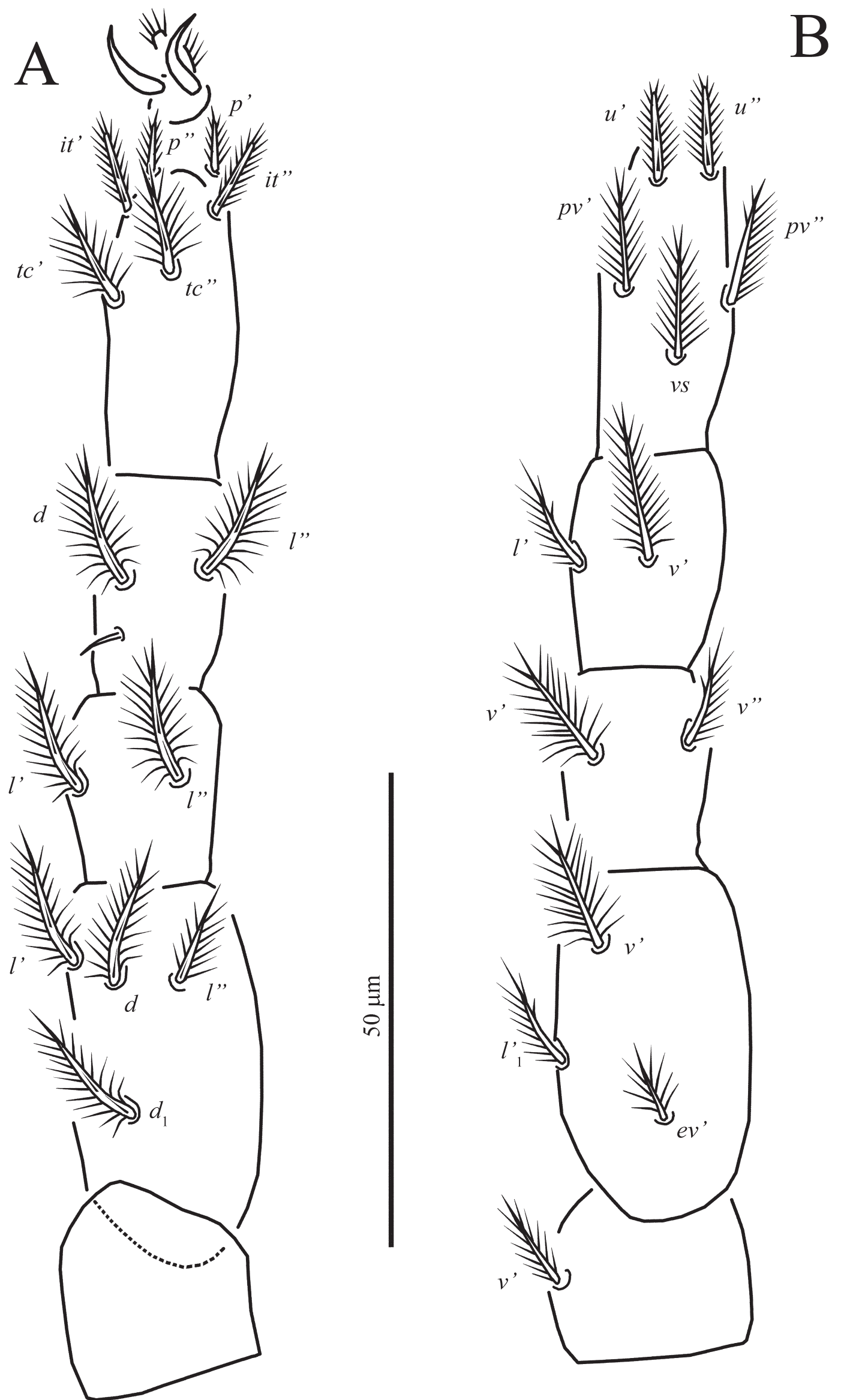

Fig. 13 Echinoeupodes echinus sp. n., deutonymph: A-leg III in dorsal view, B-leg III in ventral view. 
A
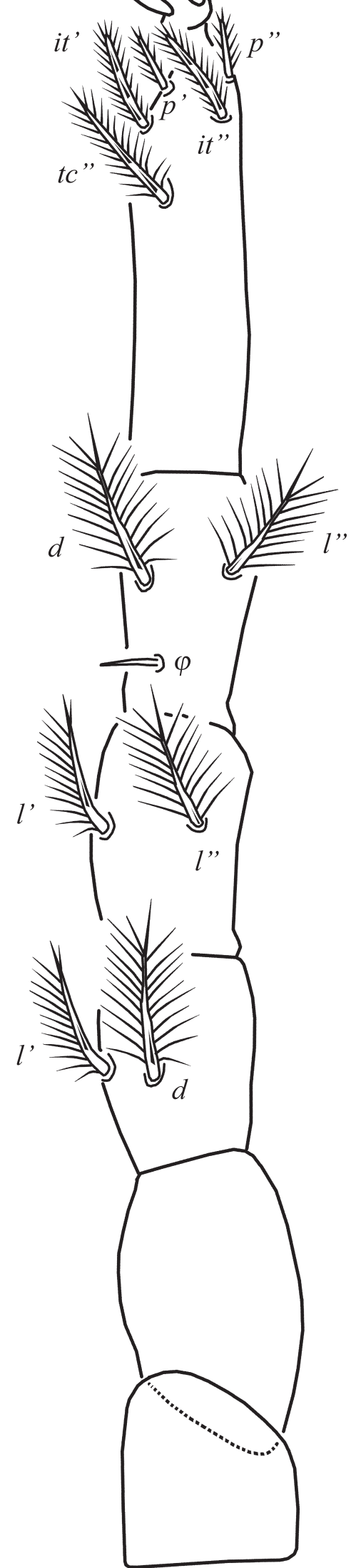

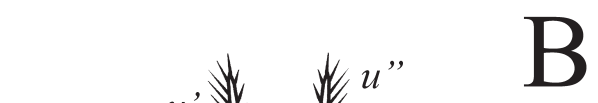

छ)

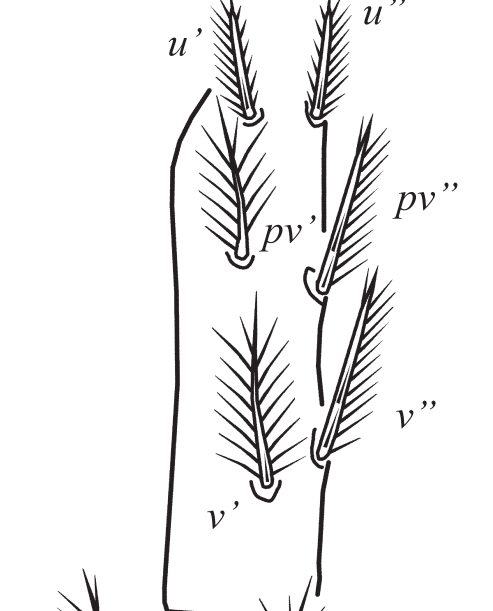

B

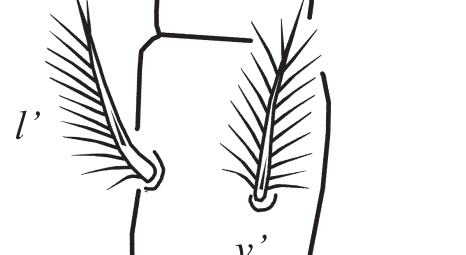

$v^{\prime}$
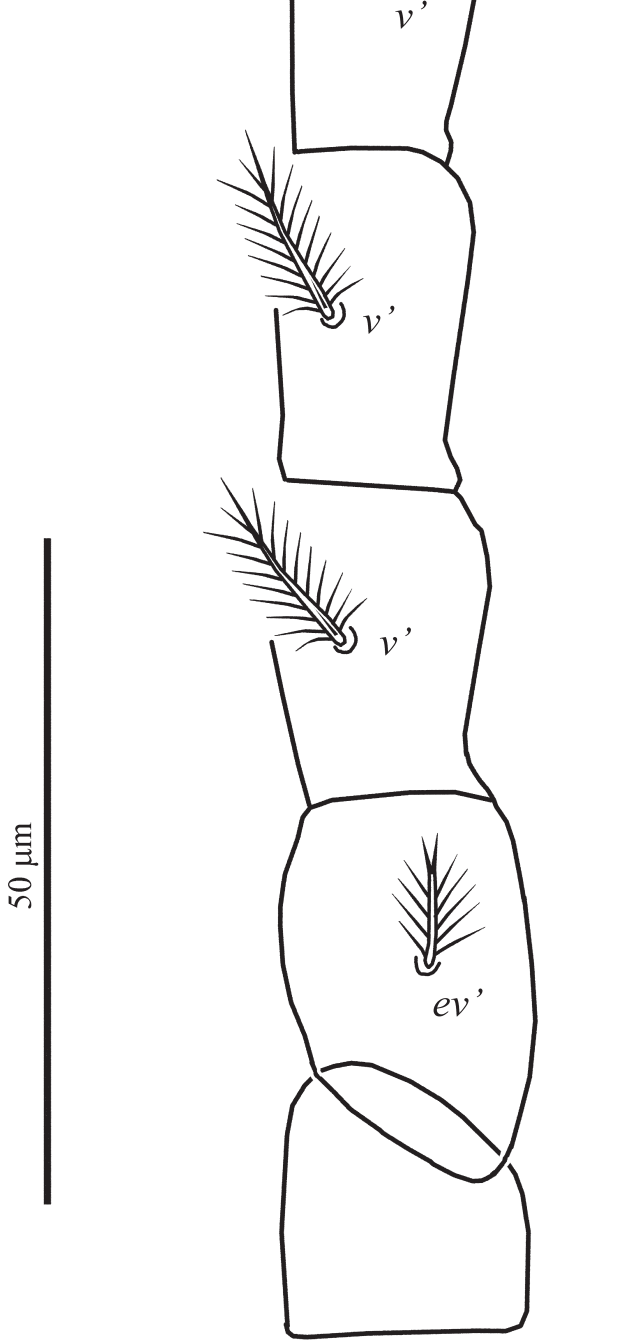

Fig. 14. Echinoeupodes echinus sp. n., deutonymph: A-leg IV in dorsal view, B-leg IV in ventral view. 
upodes gen. $\mathrm{n}$. is also unique, it is rather narrow, thin-walled and continuing into very long oesophagus. In most eupodid mites pharynx short and wide, without visible oesophagus.

\section{ACKNOWLEDGEMENTS}

The study was supported by the Russian Foundation for Basic Research (RFBR), research project No. 15-04-05175A.

\section{REFERENCES}

Baker, A.S. 1990. A survey of external morphology of mites of the superfamily Eupodoidea Banks, 1894 (Acari: Acariformes). Journal of Natural History, 24: 1227-1261.

Baker, A.S. (1995) A redescription of Halotydeus destructor (Tucker) (Prostigmata: Penthaleidae) with a survey of ontogenetic setal development in the superfamily Eupodoidea. International Journal of Acarology, 21: 261-282.

Baker, A.S. and Lindquist, E.E. 2002. Aethosolenia laselvensis gen. nov., sp. nov., a new eupodoid mite from Costa Rica (Acari: Prostigmata). Systematic \& Applied Acarology Special Publication, 11: $1-11$.

Grandjean, F. 1944. Observations sure les Acariens de la famille des Stigmaeidae. Archives des Sciences Physiques et Naturelles, 26: 103-131.

Jesionowska, K. 2007. Cocceupodes longisolenidiatus, a new mite species of the family Eupodidae (Ac- tinotrichida: Actinedida: Eupodoidea) from Poland. Annales Zoologici Warszawa, 57: 351-361.

Khaustov, A.A. 2014. A new genus and species in the mite family Eupodidae (Acari, Eupodoidea) from Crimea. ZooKeys, 422: 11-22.

Khaustov, A.A. 2015a. A new genus of the family Eupodidae (Acari: Eupodoidea) with the description of a new species from Crimea. Systematic \& Applied Acarology, 20: 927-936.

Khaustov, A.A. 2015b. A new species of the genus Protopenthalodes (Acari: Penthalodidae) from Crimea. Acarina, 23 (2): 139-151.

Khaustov, A.A. 2016. Rediagnosis of the genus Niveupodes Barilo, 1991 (Acari: Eupodidae) with the redescription of Niveupodes niveus Barilo. International Journal of Acarology, 42(5): 258-264.

Lindquist, E.E. and Zacharda, M. 1987. A new genus and species of Rhagidiidae (Acari: Prostigmata) from Chihuahuan Desert litter in New Mexico. Canadian Journal of Zoology, 65: 2149-2158.

Shiba, M. 1978. On some eupodiform mites from Japan (Acarina: Prostigmata). Reports of research Matsuyama Shinonome Junior College, 19: 133-152.

Walter, D.E., Lindquist, E.E., Smith, I.M., Cook, D.R. and Krantz, G.W. 2009. Order Trombidiformes In: Krantz GW, Walter DE. (Eds.) A Manual of Acarology. Third Edition. Texas Tech University Press, Lubbock, Texas, pp. 223-420.

Zacharda, M. 1980. Soil mites of the family Rhagidiidae (Actinedida: Eupodoidea). Morphology, systematics, ecology. Acta Universitatis Carolinae Biologica, 1978: 489-785. 